\title{
Distribution Flagellin Gene Variants of Salmonella Typhi in Patients with Typhoid Fever in West Kutai, East Kalimantan, Indonesia
}

\author{
Nataniel Tandirogang ${ }^{1}$, Yadi Yasir ${ }^{1, ~}$, M. Sabir ${ }^{2}$, Masyhudi Amir ${ }^{1}$, Moch. Hatta \\ ${ }^{1}$ Department Microbiology, Faculty of Medicine, Mulawarman University, Samarinda, Indonesia \\ ${ }^{2}$ Department Microbiology, Faculty of Medicine, Tadulako University, Palu, Indonesia \\ ${ }^{3}$ Molecular Biology and Immunology Laboratory for Infectious Diseases, Faculty of Medicine, Hasanuddin University, Makassar, Indonesia \\ Email address: \\ tandirogang@yahoo.com (N. Tandirogang),dryadi02@yahoo.com (Y. Yasir), destadamba@yahoo.com (M. Sabir), \\ masyhudiamir@yahoo.co.id (M. Amir), hattaram@indosat.net.id (Moch. Hatta)
}

\section{To cite this article:}

Nataniel Tandirogang, Yadi Yasir, M. Sabir, Masyhudi Amir, Moch. Hatta. Distribution Flagellin Gene Variants of Salmonella Typhi in Patients with Typhoid Fever in West Kutai, East Kalimantan, Indonesia. American Journal of Biomedical and Life Sciences.

Vol. 3, No. 5, 2015, pp. 98-103. doi: 10.11648/j.ajbls.20150305.12

\begin{abstract}
Background: Virulence of S. typhi possessed an important factor for occurrence of typhoid fever in humans. Penetration of $S$. typhi in the intestinal mucosa is an important step in the establishment of infection because it allows microorganisms to pass through the epithelial barrier. This penetration is mostly determined by the motility of bacteria. Flagella are composed of a protein called flagellin that associated with the first stage of invasion which allows the bacteria to make direct contact with host cells. Objectives: To explore distributions of Salmonella typhi flagellin gene in effort to explain pathogenesis of typhoid fever in patients with typhoid fever in West Kutai, East Kalimantan. Indonesia. Method: This study was an observational study with cross sectional design. Blood samples collected in January 2011 to December 2012 in Damai District and Barong Tongkok District, West Kutai. Blood cultures performed in patients with suspected typhoid fever, based on clinical features determined by the medical personnel. All positive culture isolate were examine for $\mathrm{Hd}, \mathrm{Hj}, \mathrm{z} 66 \mathrm{and} z 66 \mathrm{Ind}$ of flagellin genes by Polymerase Chain Reaction (PCR). Results: A total of $62 \mathrm{~S}$. typhi isolates obtained from 425 patients with clinically suspected typhoid fever. All 62 (100\%) samples found fliC $d$, fljBz66 gene was found by 47 (75.81\%) z66Ind 8 $(12.9 \%)$ respectively and there was no samples had fliC $j$. This study shows that significant differences between flagellin gene variants in relation to the incidence of gastrointestinal bleeding $(\mathrm{p}=0.034)$. Conclusion: We found three types of flagellin gene of $S$. typhi in West Kutai, they are FliC d, FljBz66 and z66Ind. S. typhi containing fliC $d$ genes provides the possibility 9 times more likely to cause gastrointestinal bleeding in patients with typhoid fever when compared with $S$. typhi containing fljBz66 genes, and 17.5 times when compared with z66Ind gene.
\end{abstract}

Keyword: Salmonella typhi, Flagellin Gene, FliCd, FljBz66, z66Ind

\section{Background}

Typhoid fever is caused by Salmonella enterica serovar typhi (S. typhi), is a major public health problem, especially in developing countries [1, 2], including Indonesia. The amount of cases of typhoid fever in the world is very difficult to determine, because the disease is known to have clinical symptoms with a very broad spectrum [3]. World Health Organization estimates there are 17 million cases of typhoid fever worldwide with an incidence of 600,000 cases of deaths each year [4]. Incidence of typhoid fever in Indonesia is still high bringing Indonesia to country with fourth highest typhoid fever burden in the world. The disease is found throughout the year with annual morbidity rate reached $157 / 100,000$ population in semi-rural areas and $810 / 100,000$ population in urban areas and increasing every year $[5,6]$.

Virulence of $S$. typhi possessed an important factor the occurrence of typhoid fever in humans. Several virulence factors such as fimbria or villi found on the cell surface of $S$. typhi which playing role in the process of adhesion and colonization to the host cells [7]. Penetration of S. typhi in the intestinal mucosa is an important step in the establishment of infection because it allows microorganisms to pass through the 
epithelial barrier. This penetration is mostly determined by the motility of bacteria. Flagella are composed of a protein called flagellin that also serves as an antigen. Flagella associated with the first stage invasion which allows the bacteria to make direct contact with host cells $[8,9]$. In most of Salmonella, there are two genes encode the flagella antigen, they are FliC and $\mathrm{fljB}$. FliC gene can express two types of flagellin namely flagellin $\mathrm{Hd}$ and $\mathrm{Hj}$ [10].

Very limited studies have been conducted to determine the population of the gene encoding the flagelllin. In this study we explore the distribution of flagellin gene variants of $S$. typhi spreading in the population, particularly in the West Kutai District, East Kalimantan.

\section{Method}

This study was an observational study with cross sectional design. Blood samples collected in January 2011 to December 2012 in the Damai District and Barong Tongkok District, West Kutai. Blood cultures performed in patients with suspected typhoid fever, based on clinical features determined by the medical personnel who treated the patient. The patient's blood cultures performed in Department of Microbiology Medical Faculty Mulawarman University and Provincial Laboratory Ministry of Health East Kalimantan. For bacterial motility and molecular biology examination conducted at the Laboratory of Microbiology and Molecular Biology Medical Faculty Hasanuddin University Makassar, Indonesia. Ethical clearance was approved by the review boards of the participating institutes and informed consent was obtained from all participants or their parents/guardians.

\subsection{Blood Culture}

Five milliliters of freshly collected blood was was taken aseptically and then inserted into the BACTEC transport medium and incubated at $37^{\circ} \mathrm{C}$ for $24-48$ hours. One milliliter of this culture was then plated on Salmonella Shigella (SS) agar (Oxoid, Basingstoke, United Kingdom), incubated for 24 hours at $37^{\circ} \mathrm{C}$, and examined for growth. If growth was present individual colonies were examined by Gram staining and identification of the bacteria was performed after subculturing on SS agar by biochemical testing with the triple sugar iron test, sulfide indole motility, methyl red Voges' Proskauer reactivity, citrate consumption, urease and decarboxylase activity, and carbohydrate fermentation of glucose, lactose, mannitol, sucrose, and arabinose.

\subsection{Preparation of $\mathrm{DNA}$}

DNA was extracted from freshly collected culture of $S$. typhi according to the diatom guanidinium isothiocyanate (GuSCN) method. For the extraction of DNA from culture, a freshly single colony of $S$. typhi sample was mixed with $900 \mathrm{uL}$ of lysis buffer $(50 \mathrm{mM}$ Tris- $\mathrm{HCl}, 5.25 \mathrm{M} \mathrm{GuSCN}$, 20mM EDTA, $0.1 \%$ Triton X-100) and centrifuged at 12,000 $\times \mathrm{g}$ for 10 minutes. To obtain the DNA, samples were lysed by incubation for 15 minutes at $18^{\circ} \mathrm{C}$ and $20 \mathrm{uL}$ of diatom suspension was added. The diatom containing the bound DNA was sedimented by centrifugation at $2,000 \times \mathrm{g}$ for 15 seconds. The diatom pellet was washed with washing buffer (5.25 M GuSCN in 0.1 M Tris-HCl, pH 6.4), rinsed with 70\% ethanol and acetone, and dried by incubation at $56^{\circ} \mathrm{C}$ for 10 minutes. The pellet was mixed with $60 \mathrm{uL}$ of $10 \mathrm{mM}$ Tris- $\mathrm{HCl}$, $\mathrm{pH} 8.0,1 \mathrm{mM}$ EDTA buffer and the DNA was eluted by incubation at $56^{\circ} \mathrm{C}$ for 10 minutes. After sedimentation of the diatom by centrifugation, the supernatant was collected and stored at $-20^{\circ} \mathrm{C}$ until PCR was performed [14]. All these PCRs should work clearly on genomic DNA template from the diatom-guanidinium isothiocyanate $(\mathrm{GuSCN})$ extraction method.

\subsection{Amplification of Flagellin Gene}

The fliC primers set for the fliC genes amplification, which will give a result of around $1500 \mathrm{bp}$ for the $\mathrm{H}$ :d antigen or about $200 \mathrm{bp}$ smaller for the $\mathrm{Hj}$ antigen. The final set is for the z66 antigen, which will give a product of about $1500 \mathrm{bp}$ if the strains are $\mathrm{z66+}$, and will give no result if they are z66-. Amplification of fliC gene was performed using primers: fliC F: TTAACGCAGTAAAGAGAG and fliC_R: ATGGCACAAGTCATTAATAC and produce a $152 \overline{1} \mathrm{bp}$ product for the $d$ allele and a $1273 \mathrm{bp}$ product for the $\mathrm{j}$ allele. Amplification of the $f l j B z 66$ was performed as previously described using z66Flag_F: ATGGCACAAGTCATCAATAC and z66Flag_R: TTAACGCAGCAGAGACAGTAC. Control PCR amplicons from the aroC gene were produced using primers aroC for: CCTGGCACCTCGCGCTATAC and aroC rev: CCACACACGGATCGTGGCG. Primers position on chromosome fliC_F 2011173 and fliC_R 2012674; aroC_F 2450480 and aro $\bar{C}$ R 2449674. The other primers are on a plasmid. Cycles is an initial denaturation at $94^{\circ} \mathrm{C}$ for $1 \mathrm{~min}$, 30 cycle at $94^{\circ} \mathrm{C}$ for $30 \mathrm{~s}, 57^{\circ} \mathrm{C}$ for $30 \mathrm{~s}$, and $72^{\circ} \mathrm{C}$ for $2 \mathrm{~min}$, flowed by an extension step of $72^{\circ} \mathrm{C}$ for 2 min [5]. For z66Ind primer set designated Ind - F: 5' ATG TCG GAA ATC AAC CGT ATC T 3' and Ind-R:5' CAG GCC GTC AAC CTG AGA C 3' were selected for the specific amplification of a 597bp segment of the Ind gene. The PZ66-A and PZ66-B primers are located in the central region of the $z 66$ gene that is largely deleted in the Ind gene and the primers Ind-F and Ind-R are located in the $5^{\prime}$ and $3^{\prime}$ portion of the Ind gene that shows homology with the z66 gene, but these primers are chosen such that the number of mismatches with this gene is too high to warrant efficient amplification of the z66 gene [11, 12]. The Ind-specific PCR was performed with after an initial denaturation at $94^{\circ} \mathrm{C}$ for $2 \mathrm{~min}$, for 35 cycles at $94^{\circ} \mathrm{C}$ for $30 \mathrm{~s}$, $55^{\circ} \mathrm{C}$ for $30 \mathrm{~s}$, and $72^{\circ} \mathrm{C}$ for $1 \mathrm{~min}$, followed by an extension step of $72^{\circ} \mathrm{C}$ for $5 \min [11]$.

\section{Results}

\subsection{Distribution of S. typhi Positive Culture}

A total of $62 S$. typhi isolates obtained from 425 patients with clinically suspected typhoid fever. In the District of 
Damai we found 191 patients with suspected to typhoid fever, and as many as $27(14: 14 \%)$ were confirmed with positive cultures. while at the District Barong Tongko there are 234 patients with suspected typhoid fever and found 35 $(14.96 \%)$ positive (Table 1$)$. In Table 1 shows that the positive blood culture only $14: 59 \%$ of 425 suspect cases examined.

Table 1. Distribution of patients with suspected fever typhoid.

\begin{tabular}{lll}
\hline Districts & No. Suspects & Positive Culture \\
\hline Damai Districts & 191 & $27(14.14 \%)$ \\
Barong Tongkok Districts & 234 & $35(14.96 \%)$ \\
Total & 425 & $62(14.59 \%)$ \\
\hline
\end{tabular}

\subsection{Distribution of Flagellin Gene Variants in West Kutai}

Detection of flagellin gene performed by PCR using primers fliC_F5'-TTAACGCAGTAAAGAGAG-3 'fliC_R 5'ATG GCA ATT CAA AATAC GTC-3' which will produce all the 1,521 bp fragment for the gene encoding Hd and 1,273 bp for the $\mathrm{Hj}$. Detection of flagellin gene encoding Z66 gene using a primer z66_F 5'ATG CAA GCA GTC AATAC ATC-3 'and z66_R 5'TTAACGCAGCAGAGACAGTAC-3' which will generate $1500 \mathrm{bp}$ fragment. Detection of z66Ind using Ind-F: 5 'ATG TCG GAA ATC AAC CGT ATC T 3' and IndR: 5 'CAG GCC GTC AAC CTG AGA C 3' that will produce fragments 597 bp $[11,13]$. Results of detection of $S$. typhi flagellin gene showed in figure 1 and 2 below.

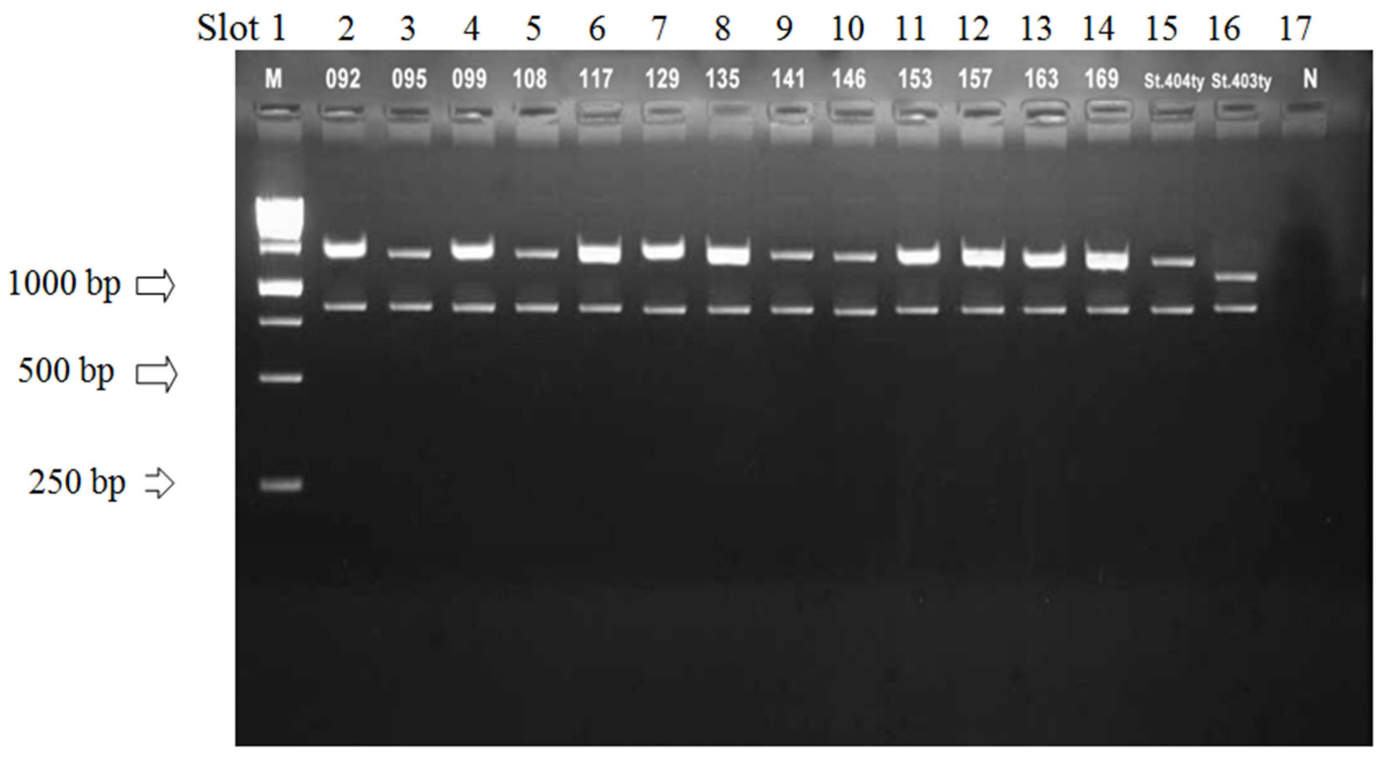

Figure 1. Electrophoresis PCR products with AroC Primer that produce fragments of $800 \mathrm{bp}$, fliC fragments $1521 \mathrm{bp}$ for the Hd, fragments $1273 \mathrm{to} \mathrm{Hj}$, and z66 1500 bp fragments (slot $1=$ Marker $1 \mathrm{~kb}$, slot 2-14= sample, slot $15=$ fliC d positive control, slot $16=$ fliC $\mathrm{j}$ positive control, slot $17=$ negative control).

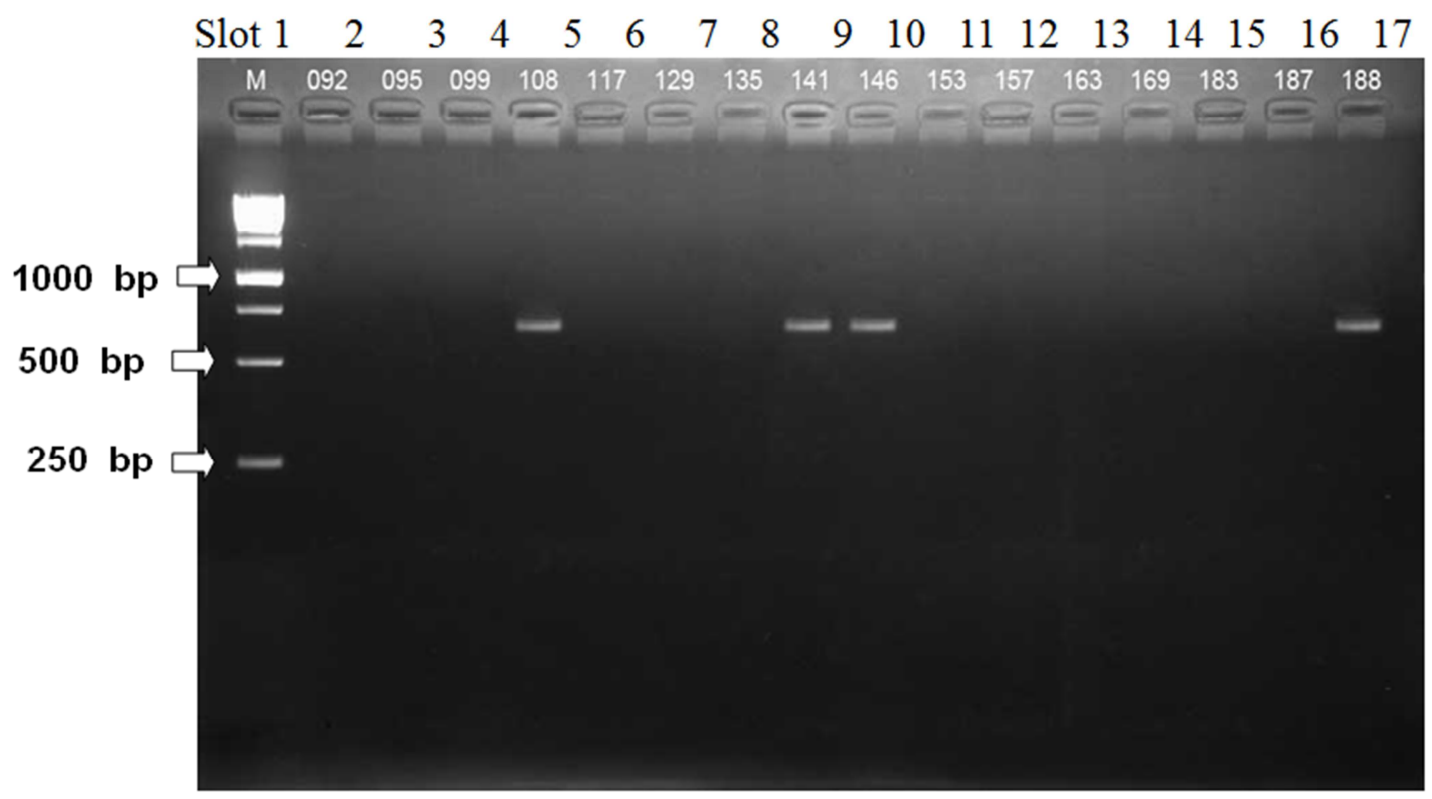

Figure 2. Electrophoresis of PCR product of z66Ind with 597bp fragments (slot $1=$ Marker $1 \mathrm{~kb}$, slots 2-17 = samples). 
Table 2. Distribution of flagellin gene S. typhi in West Kutai.

\begin{tabular}{|c|c|c|c|}
\hline \multirow[b]{2}{*}{ Flagellin genes } & \multicolumn{3}{|c|}{ Positive isolates } \\
\hline & $\begin{array}{l}\text { Damai } \\
\text { district }\end{array}$ & $\begin{array}{l}\text { Barong Tongkok } \\
\text { district }\end{array}$ & Total \\
\hline$f l i C d$ & $2(28.6 \%)$ & $5(71.4 \%)$ & $\begin{array}{l}7(11.29 \%) \\
(\mathrm{SD}=0.3)\end{array}$ \\
\hline$f l i C j$ & 0 & 0 & $0(\mathrm{SD}=0.0)$ \\
\hline$f l i C d+f l j B z 66$ & $25(53.2 \%)$ & $22(46.8 \%)$ & $\begin{array}{l}47(75.81 \%) \\
(\mathrm{SD}=0.4)\end{array}$ \\
\hline$f l i C d+z 66$ Ind & 0 & $8(100 \%)$ & $\begin{array}{l}8(12.9 \%) \\
(\mathrm{SD}=0.3)\end{array}$ \\
\hline Total & $27(43.5 \%)$ & $35(56.5 \%)$ & $62(100 \%)$ \\
\hline
\end{tabular}

Table 2 shows that all $62(100 \%)$ samples found $\mathrm{fliC} d$, fljBz66 gene was found by 47 (75.81\%) z66Ind 8 (12.9\%) and no $(0 \%)$ samples had $\mathrm{fliC} j$, This result is slightly different with previous studies in several places in Indonesia, because $f l i C j$ genes was not found. Sabir et al., (2014) in Palu found $F l i C d$, fliC j, fljBz66 and z66Ind; 9.9\%, 22.7\%, $39.7 \%$ and $27.7 \%$ respectively. Baker et al., 2008 in Jatinegara find where $f l i C d, f l i C j$ and $f l j B z 66$ by 85 (61\%), 55 (40\%), and 59 (42\%) respectively. Research conducted by Hatta et al., 2011 on isolates originating from Eastern Indonesian Islands find fliC $d$ in $100 \%$ of samples, fljBz66 $15.4 \%$, z66Ind $21.8 \%$, but fliC $j$ was not found. Study conducted by Song et al. in Korea on 375 isolates of S. typhi found only one isolate that has $\mathrm{Hj}$ but it considered Indonesian strain because the patient is showing symptoms of typhoid fever while in Indonesia.

In this study we also analyzed the relationship between flagellin gene variants between typhoid fever patients with gastrointestinal bleeding complications presented in Table 3.

Table 3. Relationship between flagellin gene variants between typhoid fever patients with gastrointestinal bleeding complications.

\begin{tabular}{|c|c|c|c|c|c|c|c|}
\hline \multirow{3}{*}{$\begin{array}{l}\text { Flagellin } \\
\text { gene } \\
\text { variants }\end{array}$} & \multicolumn{4}{|c|}{$\begin{array}{l}\text { Gastrointestinal bleeding } \\
\text { complications }\end{array}$} & \multirow{3}{*}{$\mathbf{P}$} & \multirow{3}{*}{ OR } & \multirow{3}{*}{ CI 95\% } \\
\hline & \multicolumn{2}{|c|}{ Positif } & \multicolumn{2}{|c|}{ negatif } & & & \\
\hline & $\mathbf{n}$ & $\%$ & $\mathbf{n}$ & $\%$ & & & \\
\hline $\begin{array}{l}\text { fliCd }+ \\
\text { z66Ind }\end{array}$ & 1 & 12.5 & 7 & 87.5 & 0.035 & 17.500 & $\begin{array}{l}(1.22 ; \\
250.36)\end{array}$ \\
\hline $\begin{array}{l}\text { fliC } d+ \\
\text { fljBz66 }\end{array}$ & 10 & 21.3 & 37 & 78.7 & 0.014 & 9.250 & $\begin{array}{l}(1.556 \\
54.98)\end{array}$ \\
\hline fliC $d$ & 5 & 71.4 & 2 & 28.6 & Ref & & \\
\hline Total & 16 & 25.8 & 46 & 74.2 & 0.034 & & \\
\hline
\end{tabular}

In Table 3 shows that significant differences between flagellin gene variants in relation to the incidence of gastrointestinal bleeding. $(\mathrm{p}=0.034)$. Furthermore, no significant difference $(\mathrm{p}=0.014)$ between fliC $d$ with fljBz66 with OR at 9.25, there was a significant difference $(\mathrm{p}=0.035)$ between fliC $d$ with $z 66$ Ind with OR at 17.50. These results indicate that the presence of flagellin gene fliC $d$ likely to cause gastrointestinal bleeding of 9.2 times greater when compared with the presence of the gene fljBz66 and 17.5 times greater when compared with the presence of the gene z66Ind. Similar results were conducted by Grossman (1995) on isolates of S. typhi in Jakarta, Yogyakarta, Palembang and
Surabaya, showed a correlation between motility and the presence of flagellin gene variants. Hd strains show motility and invasiveness higher than $\mathrm{Hj}$ [14]. Likewise with the clinical picture caused by strain Hd worse than the serotype $\mathrm{Hj}$. Chanh (2004) concluded that the deletions on $\mathrm{Hj}$ strain causing a less efficient interaction with cell surface receptors, thereby reducing the ability of invasive and virulence of this serotype [15].

\section{Discussion}

Results of this study indicate that there are genetic biodiversity on flagellin genes in Kutai Barat. There are 3 variations of flagellin gene that is fliC $d, f l j B z 66$ and z66Ind. fljBz66 and z66Ind not commonly found in other countries. The results support the previous information has also been carried out in several major cities in Indonesia including Jakarta, Yogyakarta, Palembang, Surabaya, Makassar and Palu. An interesting result of this study was $\mathrm{Hj}$ genes that are not found as frequently found in other regions of Indonesia. Intensive research conducted in Africa, India, Israel, Mexico, Madagascar, Nepal, Singapore, Thailand, the United States and other countries have failed to find any gene encoding $\mathrm{Hj}$. Indonesia with a high incidence of typhoid fever $\mathrm{Hd}$ and $\mathrm{Hj}$ commonly found, but absence of $\mathrm{Hj}$ in West Kutai may relate on a mechanism of flagellin genes regulated by fljA.

According to Grossman, et al., 1995 and Baker et al., 2008, basically $\mathrm{Hj}$ genes are highly homologous with $\mathrm{Hd}$, except for deletion of $261 \mathrm{bp}$ in the central part $f l i C j$ genes which is responsible for the flagellin gene variation [5, 14]. This deletion occurs as a result of homologous recombination intragenic involving the repetition of $11 \mathrm{bp}$. Flagellin gene expression on Salmonella is controlled by repeated inversion of DNA segments called $\mathrm{H}$ segment, which contains promoter fljB. $\mathrm{H}$ inversion occurs through a specific part recombination between inverted repeated sequence flanking $\mathrm{H}$ segments. FljB and $\mathrm{flj} \mathrm{A}$ gene construct operon that encodes a negative regulator for $\mathrm{FliC}$ expression. FljA gene inhibits the expression of FliC through post transcriptional control mechanisms [16-18].

Z66 gene encoded by extra chromosomal DNA or plasmid is called pBSSB1 [5]. This is different from $\mathrm{Hd}$ and $\mathrm{Hj}$ encoded on the chromosome. $\mathrm{Zu}$, et al. reported a difference in expression z66 and FliC on osmotic pressure, bile acids and oxidative stress [19]. Flagelin gene variations found in this study indicate that there is a process of $S$. typhi adaptation on chromosomes and plasmids. Changes in the DNA are a bacterial adaptation in an effort to defend them gradually and continuously. Adaptation of living organisms including bacteria to environmental changes is a response to natural selection for survival. According to Okazaki et al., Genetic processes between flagellin genes for example in point mutation, deletion and insertion as a phenomenon that can describe the lateral transfer of genetic material that produces inter specific recombination between flagellin genes. In addition to these processes, the interaction between 
genes fliC and fliB also considered one of the causes of biodiversity flagellin genes in Salmonella serovar [20].

Controversy of several studies on the correlation between the type of flagellin and the motility or the virulence properties of $S$. typhi triggers intensive research by experts to undertake a thorough study of the motility and invasiveness of $S$. typhi in vivo. Flagella mediated motility is one of the factors that play a role in the invasion of the host cell. Flagella function associated with the first stage invasion in which motility and chemotaxis power causing bacteria make direct contact with host cells. Reduced function of motility in serotypes $\mathrm{Hj}$ as a result of changes in the function of flagella would result in reducing invasion power.

\section{Conclusion}

In this study, we found three types of flagellin gene of $S$. typhi in West Kutai, namely; fliC $d$, fljBz66 and z66Ind. The absence fliC $\mathrm{j}$ gene of S. typhi in West Kutai indicate that this event is not common in Indonesia, it would be a challenge for further research whether flagellin gene variation $\mathrm{S}$. typhi is the original clone or clones that are distributed from the surrounding areas.

S. typhi with fliC d more invasive compared to others, it can be shown on these data where fliC $d$ containing genes provides 9 times more likely to cause gastrointestinal bleeding in patients with typhoid fever when compared with $S$. typhi containing fljBz66 genes, and 17.5 times when compared with z66Ind gene.

\section{Acknowledgments}

The authors wish to thank Drs. Zulkarnaen, M. Kes as the Head of District Health Office of West Kutai Regency, Drs. Zulkarnaen, M. Kes the Director of Insan Harapan Hospital Sendawar, Sukwanto, S. Kep, Ns, M.Si, Head of Primary Health Center Barongtongkok that allow us to conduct research in the region. We acknowledge Mr. Aris SKM, Head of Floating Health Center KM Mook Manaar Bulan and all crews that has allowed us to go sailing for weeks along the Mahakam river. We acknowledge Sister Bonifatio, MASF, dr. H. Bambang Setyo Basuki, Sp PD, who helped us find suspected typhoid fever patients in Harapan Insan Sendawar Hospital. Thank you to Mr. H. Abd. Khairin, for guided us in the field to collecting data.

\section{References}

[1] Crump JA, Mintz ED: Global trends in typhoid and paratyphoid Fever. Clinical infectious diseases: an official publication of the Infectious Diseases Society of America 2010, 50(2):241-246.

[2] Sankar S, Kuppanan S, Nandagopal B, Sridharan G: Diversity of Salmonella enterica serovar Typhi strains collected from india using variable number tandem repeat (VNTR)-PCR analysis. Molecular diagnosis \& therapy 2013, 17(4):257-264.
[3] Ley B, Mtove G, Thriemer K, Amos B, von Seidlein L, Hendriksen I, Mwambuli A, Shoo A, Malahiyo R, Ame SM et $a l$ : Evaluation of the Widal tube agglutination test for the diagnosis of typhoid fever among children admitted to a rural hdospital in Tanzania and a comparison with previous studies. BMC infectious diseases 2010, 10:180.

[4] (WHO) WHO: Background document: The diagnosis, treatment and prevention of typhoid fever. In. Geneva: World Health Organization.; 2003.

[5] Baker S, Holt K, van de Vosse E, Roumagnac P, Whitehead S, King E, Ewels P, Keniry A, Weill FX, Lightfoot D et al: Highthroughput genotyping of Salmonella enterica serovar Typhi allowing geographical assignment of haplotypes and pathotypes within an urban District of Jakarta, Indonesia. Journal of clinical microbiology 2008, 46(5):1741-1746.

[6] Moehario LH: The molecular epidemiology of Salmonella Typhi across Indonesia reveals bacterial migration. Journal of infection in developing countries 2009, 3(8):579-584.

[7] Burrows LL: Weapons of mass retraction. Molecular microbiology 2005, 57(4):878-888.

[8] Hughes KT, Gillen KL, Semon MJ, Karlinsey JE: Sensing structural intermediates in bacterial flagellar assembly by export of a negative regulator. Science 1993, 262(5137):12771280.

[9] Josenhans C, Niehus E, Amersbach S, Horster A, Betz C, Drescher B, Hughes KT, Suerbaum S: Functional characterization of the antagonistic flagellar late regulators FliA and FlgM of Helicobacter pylori and their effects on the H. pylori transcriptome. Molecular microbiology 2002, 43(2):307-322.

[10] McQuiston EA: Sequencing and comparative analysis of flagellin genes fliC, fljB, and flpA from salmonella. Journal of clinical microbiology 2004, 42(5):1923-1932.

[11] Mochammad Hatta ARS, Rob Pastoor, Henk L. Smits: New Flagellin Gene for Salmonella enterica serovar Typhi from the East Indonesian Archipelago. Am J Trop Med and Hyg 2011, 84: 429-434.

[12] Huang X PV, Dejsirilert S, Tishyadhigama P, Li Y, Liu H, Hirose K, Kawamura Y, Ezaki T: Cloning and characterization of the gene encoding the z66 antigen of Salmonella enteric serovar typhi. FEMS microbiology letters 2004, 234:239-246.

[13] Sabir M, Dwiyanti R, Febrianty A, Tandirogang N, Yasir Y, Sultan AR, Purnamasari NI, Primaguna MR, Muhammad M, Amir M et al: Relationships between Flagellin Genes Variants of Salmonella enterica Serovar Typhi and Severity of Illness from Acute and Carriers State of Typhoid Fever American Journal of Infectious Diseases and Microbiology, 2014, 2(4):74-80.

[14] Grossman DA, Witham ND, Burr DH, Lesmana M, Rubin FA, Schoolnik GK, Parsonnet J: Flagellar serotypes of Salmonella typhi in Indonesia: relationships among motility, invasiveness, and clinical illness. The Journal of infectious diseases 1995, 171(1):212-216.

[15] Quoc CN, Paul E, Tan KT, Deborah H, Simon M, Christopher P, Phillippa C, Van BP, Song DT, Pietro M et al: A Clinical, Microbiological, and Pathological Study of Intestinal Perforation Associated with Typhoid Fever. Clinical Infectious Diseases 2004, 39:61-67. 
[16] Aldridge PD, Wu C, Gnerer J, Karlinsey JE, Hughes KT, Sachs MS: Regulatory protein that inhibits both synthesis and use of the target protein controls flagellar phase variation in Salmonella enterica. Proceedings of the National Academy of Sciences of the United States of America 2006, 103(30):11340-11345.

[17] Bonifield HR, Hughes KT: Flagellar phase variation in Salmonella enterica is mediated by a posttranscriptional control mechanism. Journal of bacteriology 2003, 185(12):3567-3574.

[18] Yamamoto S, Kutsukake K: FljA-mediated posttranscriptional control of phase 1 flagellin expression in flagellar phase variation of Salmonella enterica serovar Typhimurium. Journal of bacteriology 2006, 188(3):958-967.

[19] Shungao X, Haifan Z, Xiumei S, Huaxi X, Xinxiang H: Transcriptional expression of fljB:z66, a flagellin gene located on a novel linear plasmid of Salmonella enterica serovar Typhi under environmental stresses. New Microbiologica 2008, 31:241-247.

[20] Okazaki N, Matsuo S, Saito K, Tominaga A, Enomoto M: Conversion of the Salmonella phase 1 flagellin gene fliC to the phase 2 gene $\mathrm{fljB}$ on the Escherichia coli K-12 chromosome. Journal of bacteriology 1993, 175(3):758-766. 